Article

\title{
The Importance of Price in Poland's Carp Market
}

\author{
Magdalena Raftowicz ${ }^{1, *(1)}$, Mirosław Struś ${ }^{2}\left(\mathbb{D}\right.$, Michał Nadolny $^{3}(\mathbb{C}$ \\ and Magdalena Kalisiak-Mędelska ${ }^{1}$ (D) \\ 1 Institute of Economics Sciences, Faculty of Life Sciences and Technology, Wroclaw University of \\ Environmental and Life Sciences, 50-375 Wroclaw, Poland; magdalena.kalisiak-medelska@upwr.edu.pl \\ 2 Institute of Economics Sciences, Faculty of Law, Administration and Economics, University of Wroclaw, \\ 50-137 Wroclaw, Poland; miroslaw.strus@uwr.edu.pl \\ 3 Department of Process Management, Faculty of Management, Wroclaw University of Economics \\ and Business, 53-345 Wroclaw, Poland; michal.nadolny@ue.wroc.pl \\ * Correspondence: magdalena.raftowicz@upwr.edu.pl
}

Received: 17 October 2020; Accepted: 10 December 2020; Published: 12 December 2020

check for updates

\begin{abstract}
Poland is one of Europe's key carp producers. However, its main consumption (80-90\% of sales) is concentrated during the Christmas period. In addition, the marginal sale of fish outside the core season does not allow producers to extend the period for generating revenues. Price is one of the essential factors for determining the behavior of both producers and consumers. In this context, our research addressed the role of price on Poland's carp market, approaching it as a specific product due to its nature and Polish tradition. Moreover, an attempt was made to indicate the existing correlations between quality factors and the price of carp. The problem of price was examined primarily from the consumer's perspective. Nevertheless, a simplified simulation of the effect of price on supply was also performed, especially with regard to the development of direct sales. The source material was obtained through a survey conducted among the consumers from Wroclaw, the main urban center of Lower Silesia, located a short distance from the largest complex of carp fishponds in Poland. The research results were statistically processed in the Statistica program. The findings, however, did not confirm that price was a factor in determining the purchasing behavior of consumers in Poland's carp market. Non-price factors related to consumer tastes and preferences (seasonality of demand) played a much greater role. Therefore, the efforts aimed at restoring balance on the analyzed market should be focused on enhancing consumers' perception of carp as a high-quality fish presenting health oriented qualities.
\end{abstract}

Keywords: price; food quality; carp market

\section{Introduction}

According to the generally accepted opinion in economic theory, price acts as the primary market regulator [1]. Increasing or decreasing this factor ought to result in market equilibrium. Price should also determine the behavior of both consumers and producers [2].

In addition, price is one of the basic marketing instruments and, at the same time, the most dynamic one [3]. Setting prices and competing with them is one of the most difficult parts of marketing management. Many mistakes are frequently made, which results from ignorance of market specificity or consumer habits. When entering the market, the price is usually set relatively low to generate a higher market share. It is based on the assumption that a low price is expected to generate a certain demand, which allows for the producer to increase production to a profitable volume.

In most Polish food production companies, prices are treated in an extremely traditional way [4]. The basis for their determination is most often related to production costs. From this perspective, it is 
difficult to find any specific marketing strategy. In many cases, the pricing policy of enterprises is aimed at surviving in a difficult period.

From a consumer perspective, prices play an important role in food purchasing decisions, although this trend is changing. A slow transformation in consumer orientation on the food market has had a declining role in price and a growing importance of quality for making purchasing decisions. The wealthier part of society has shown a greater interest in improving the quality of goods. In view of the increase in wealth after the accession to the European Union, which is undoubtedly observed in Poland, the quality requirements are rapidly increasing.

The growing interest in regional and traditional products [5] is a new phenomenon observed among customers that can be related to:

- the development of slow food culture [6];

- the increasing importance of food safety [7];

- the development of marketing focused on region and tradition [8,9];

- the increasing importance of regional and traditional product labelling [10];

- the growing popularity of the consumer ethnocentrism attitude [11], which in Poland is particularly visible in relation to food products [12];

- the growing number of consumers who, when buying food, are increasingly looking for proven, good quality, and well-known products, often regardless of the price [13];

- the growing number of consumers (the so-called "locavore") who attach increasing importance to local food that is not transported over long distances [14], according to the idea of shortening the food supply chain [15];

- $\quad$ rising interest in natural products [16].

The example of carp consumption in Poland clearly illustrates these phenomena. It results from the fact that, in Poland, carp farming has still retained its traditional character in terms of feeding or harvesting. This is due to the tradition of pond fish farming in Poland dating back to the 11th and 12th century. It was connected with the activities of the Cistercian Order, which played a special role in organizing and using pond facilities in that period. Along with the Christian religion strengthening in Poland, there was a need to observe numerous fasts (over 200 days per year), thus increasing the demand for fish. At that time, huge yet shallow ponds with a 100-1000 ha unit area were established. To this day, they survive in a truncated form and currently function as valuable natural areas.

Today, carp specificity still rests on low production intensification (up to $1500 \mathrm{~kg} / \mathrm{ha}$ ), a large share of natural food (growing in the pond) in fish diet (half of fish growth comes from plankton), or the use of unprocessed, natural cereals in carp feeding, which significantly increases their taste (and perceived quality) [12].

This close to natural form of fish farming is gaining recognition on the demand side, because the group of buyers ready to pay a higher price for healthy and fresh fish is slowly but systematically growing. These buyers are interested in the problems of ecology and sustainable development, their consumption is qualitative rather than quantitative, and they adhere to values such as responsibility, honesty, and safety [17].

However, the specificity of Poland's carp market is unique and incomparable to other seasonal product markets worldwide. This is due to the fact that $80-90 \%$ of its consumption falls on 1 day a year only, which is related to the Christmas tradition when carp is an obligatory dish on the Christmas Eve table, as results from the Christian tradition. Apart from Christmas season, there is no demand for carp among consumers.

The main purpose of this research was to estimate the price importance for carp in Poland. Additionally, the article attempted to answer whether there were any data correlations between quality factors and carp price, and also how to increase annual carp consumption, including direct sales. Finding the solution to the presented problems is of fundamental importance for the proper understanding of how the carp market functions, which brings the sale of about 120 to 130 million 
Euro annually. However, it should be emphasized that $75 \%$ of total carp production comes from four countries only, i.e., Poland, the Czech Republic, Germany, and Hungary (data for 2015) [18]. In this article, we analyzed the price of carp from a consumer's perspective. Nevertheless, for a more comprehensive picture of the market, a simplified simulation of the price impact on supply was also carried out, particularly on the possibility of developing direct sales.

The goals formulated in this way defined the structure of the article. Section 2 presents the characteristics of Poland's carp market based on the example of the Barycz Valley, which is where the biggest carp center in Europe is situated. Section 3 addresses the materials and methods. Section 4 describes surveys results conducted among carp consumers, which is the main part of the article. Sections 5 and 6 summarize the considerations and sequentially present the discussion and conclusion.

\section{Characteristics of Poland's Carp Market}

At the end of the 20th century, the volume of fish supply for consumption was determined by sea catches. However, over the past two decades, a slowdown or even decline in sea fish catches has been observed as a result of overfishing. Currently, fish product supply has been taken over by intensely developing aquaculture, including the production of freshwater fish.

In Poland, a specific form of aquaculture has developed, i.e., pond carp management. It is almost unknown in Western European, as it is dominated by trout farming. Poland has the largest carp pond area in the European Union. As a result, Poland is also the largest carp producer in the EU. It is worth emphasizing that, practically, the entire production is intended for the domestic market [19]. In 2017, carp sales in Poland reached 20.8 thousand tons. Domestic production was the dominating factor on the market (18.6 thousand tons). Imports amounted to $15.1 \%$ of the domestic production, of which $80 \%$ originated from the Czech Republic [20]. The remaining amounts were imported from Hungary, Lithuania, and even China [21].

Unfortunately, since the beginning of the 21st century, the downward trend in carp production has increased despite the industrial fishing sector's strategy to develop aquaculture both in Poland and throughout the EU [22]. Until now, the carp industry has not been able to take advantage of the development potential offered by the freshwater fish market, even though carps are the most popular and recognizable fish for Polish consumers. Unfortunately, Poland's carp market is still characterized by high seasonality. A very characteristic feature of the carp market is the fact that $80-90 \%$ of sales take place around Christmas, which is related to the Polish Christian tradition to serve carp as a main dish on Christmas Eve. For a decade, efforts have been made to promote the year-round consumption of this fish.

Until recently, the Polish food consumption model was characteristic for Baltic countries along with low income levels. The so-called Baltic model is characterized by a very high consumption level of poultry, sugar, animal fats, butter, potatoes, cereals (high consumption), pork (average consumption), legumes (low consumption), vegetables, fruit, vegetable oils, and a very low consumption of fish/seafood, beef, sheep, goat meat, and milk. This diet favors a comparatively low consumption of animal protein, with a relatively low energy value [23].

The basis of the statistical Pole's diet is still warm-blooded animal meat (predominantly pork and poultry), with a small addition of fish.

The above statements were reflected in the results of the research presented in the Fish Market Report 2018. It shows that in Poland in 2018, fish and seafood consumption was $12.5 \mathrm{~kg}$ per inhabitant per year, of which $10.9 \mathrm{~kg}$ was sea fish and $1.6 \mathrm{~kg}$ was freshwater fish. At the same time, carp consumption in 2018 reached the level of $0.56 \mathrm{~kg} /$ inhabitant per year [12]. Over the years 2012-2018, the consumption of carp per capita increased by less than $10 \%$. According to other studies [17], Poles consume, on average, $4.2 \mathrm{~kg}$ of carp per year.

Therefore, the carp market is characterized by permanent imbalance. The sources of this situation are ingrained in the supply and demand chain. In the case of supply, both fragmentation and concentration of sales during Christmas season is observed and, as a result, according to the 
surveys carried out on large farms, about $80-90 \%$ of carp sales are recorded during this period [12]. Simultaneously, there are problems with selling carp out of this season. Such situations may be affected by a limited range of carp products focused on selling live fish. In addition, poorly developed carp processing acts as an obstacle to selling fish and their products to restaurants and other mass caterers.

The production of carp is a specific type of activity. Its production cycle usually takes 3 years, during which it is difficult to predict risks (such as droughts, floods, and fish diseases). The specificity of the carp economy is also closely related to the functioning of the European Ecological Network Natura 2000. For example, in the Barycz Valley, which is the largest carp breeding center in Poland, covers practically the entire fishpond area. Within the framework of this program, such bird species as grey heron, eagle, and black cormorant are under special protection. As a result, fishermen are "doomed" to lower farming efficiency and lower profitability of fish production, which is also due to the absence of compensation for damages caused by piscivores.

In addition, the dumping prices of fish offered by large retail chains selling carp at a price lower than its production costs around Christmas also remain a big threat to carp producers. These carps are most frequently imported from countries not covered by the Natura 2000 program. Currently, it is estimated that every fifth carp sold in Poland is imported [17].

Moreover, the profitability of fish production (measured by the ratio of revenues against costs) is highly volatile, which results from the absence of full control over all elements of the three-year production process. The financial result depends on the size of farms, their legal status, the degree of income diversification, the possibility of acquiring investment funds, competitive potential, and pro-marketing orientation [24].

It is also important to understand the changing needs of consumers in running a carp breeding business. The studies conducted in 2014 showed that even those who consider carp both tasty and healthy consider the following factors to discourage them from buying and eating carp [25]: offering mostly whole, unprocessed fish for sale (35\%), high boniness of carp meat $(25.2 \%)$, and the need to trim whole carps in household conditions. Therefore, the challenge is to develop food and catering outlets.

An additional barrier is the deeply rooted Polish tradition of carp consumption during the Christmas season. Outside the holiday season, consumers do not generate demand for carp adequate to the scale of its production on fish farms. According to the existing research, in the remaining months of the year, the consumption of freshwater fish is 10 times lower [17].

This situation is the essential reason for the aforementioned imbalance on the carp market. In 2016, the average sale price of live carp amounted to PLN 13.26 and was comparable to the price of pork, but was higher than the price of poultry [17]. It is worth highlighting, however, that it was lower than the price presented later in the article, which is considered acceptable to consumers. Therefore, the following question arises: Why is the market characterized by a state of imbalance? The surplus of carp supply is over its demand, since the price per $1 \mathrm{~kg}$ of carp is lower than the price preferred by consumers. This raises yet another question: Does the price actually play the role of a regulator in the carp market? Providing the answer to the above question is the purpose of this article. In addition, the article attempts to answer whether there are any correlations between qualitative factors and the price of carp.

\section{Material and Methods}

The main purpose of this study was to determine carp prices preferred by consumers as well as to estimate the unit cost of product delivery to consumers. The second purpose was to analyze whether consumers' purchasing preferences affected their willingness to pay a higher price for the product. It seemed natural for customers to be charged an additional cost for home delivery [26], and it can also be presumed that the price is influenced by certain individual preferences [27], as well as the product seasonality [28]. Therefore, the authors of this study put forward the following research hypotheses: 
Hypothesis 1 (H1): The price per kilo carp, including home delivery, is significantly higher than the price of a carp purchased from a producer/seller.

Hypothesis 2 (H2): There are purchasing preferences that affect a consumer's willingness to pay a higher price for carp.

Hypothesis 3 (H3): The Christmas period affects the price of carp preferred by consumers.

Verification was based on the source material collected as a result of the survey conducted in 2019 (June-July) among consumers living in Wroclaw. The adopted spatial scope of the study resulted from the fact that it is the largest urban center in Lower Silesia Province and the core market for carp produced in the main carp production center in Poland, but also in Europe, located approximately $70 \mathrm{~km}$ away, i.e., in the Barycz Valley (7500 ha of ponds) (Figure 1). In addition, it was assumed, based on previous research by Raftowicz-Filipkiewicz et al. [29], that the interest in organic, regional, or traditional products was characteristic for conscious, educated people presenting a specific personality profile and material status who were determined to purchase products offering the expected quality attributes.

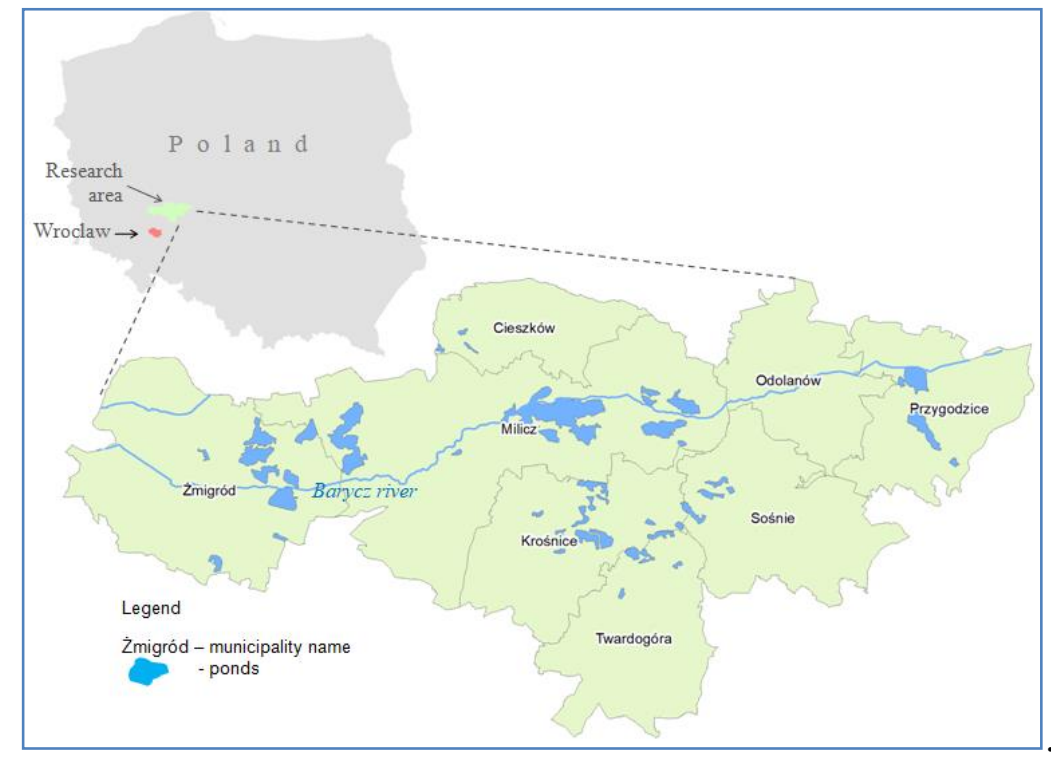

Figure 1. Map of the Barycz Valley where carp is cultured.

The survey questionnaire consisted of 24 questions (Appendix A) and was sent to 139 people who met the abovementioned assumptions. The sample size was sufficient to assess whether consumers were willing to pay more (and by how much) for home-delivered organic fish. It also allowed us to assess whether the quality factors influenced consumers' tendency to accept a higher price for organic fish. The general conclusions reflected consumer behavior in terms of the entire carp market in Poland. It is not strongly diversified regarding product range offer, production costs, customer structure, or the competitive position of producers.

The verification of the above research hypotheses required using specific statistical tests based on measurable variables (price from a producer and price with delivery). The preliminary data analysis allowed us to conclude that statistical distributions of both analyzed quantitative variables at $\alpha=0.05$ significance level did not meet the Gaussian distribution function. The assumption of equal variance was not met either. It was verified based on Levene's test [30], where p-value equaled 0.03 . Therefore, in order to check whether producers' delivery prices and purchase prices differed from each other, the Kolmogorov-Smirnov test [31] was used. The analysis of the influence of preferences on prices was based on the nonparametric Mann-Whitney U test [32]. 
Two variables expressed in an absolute scale were measured: an accepted consumer price of carp purchased from a producer (referred to as the producer's price) and an accepted price including home delivery (referred to as price with delivery). Apart from the questions referring to price, the respondents were also asked about qualitative factors (dichotomous yes/no) that influenced their decisions:

- product brand or regional nature of the product;

- if the fish is filleted;

- fish taste;

- freshness;

- seller's location;

- producer's connections;

- culinary traditions.

The qualitative factors influencing purchase decisions also included the most popular period for carp purchase by a consumer. In addition to the cases of consumers not eating carp at all, three more possible declarations were distinguished:

- I eat regularly;

- I eat only during Christmas (traditional period of carp consumption in Poland);

- I also eat outside of the Christmas season.

\section{Results}

The results of our test clearly indicated that respondents were willing to pay more for home delivery than if they were to buy from a producer or seller. Therefore, Hypothesis 1 can be considered true: consumers are willing to pay PLN 15 for carp bought from a producer, and PLN 20 for its home delivery. The significant difference was PLN 5.

It should be emphasized that the prices specified by consumers were above the average cost of carp production at the farms located in the Barycz Valley, amounting to PLN $8.4 / \mathrm{kg}$, and above the current average market price in retail sales (PLN 14/kg).

It is worth noting that, according to the research results, consumers buy, on average, $5 \mathrm{~kg}$ of carp per year, although a typical value is $3 \mathrm{~kg}$ (median). At the same time, the prevailing consumption occurs during the Christmas period ( $80 \%$ of the respondents). Therefore, it can be assumed, with due caution, that they would be interested in a one-time purchase. Having the knowledge that consumers are willing to pay PLN 5 more per $1 \mathrm{~kg}$ of fish, and their consumption ranges between 3 and $5 \mathrm{~kg}$, it can be assumed that the delivery cost indicated by a consumer ranges between PLN 15 and 25 .

Fishing farms are located about $70 \mathrm{~km}$ away from the center of the main market (i.e., the city of Wroclaw (600,000 inhabitants)) and fish producers are willing to incur transport costs in the amount of PLN 2 per km [33]. Thus, the number of kg and customers ensuring the profitability of direct deliveries can be estimated, as presented in Table 1.

Table 1. Consumer preferences on the carp market.

\begin{tabular}{cccccc}
\hline $\begin{array}{c}\text { Preferred } \\
\text { Quantity of } \\
\text { Carp per capita }\end{array}$ & $\begin{array}{c}\text { Preferred by } \\
\text { the Consumer } \\
\text { Cost of } 1 \text { kg } \\
\text { Delivery }\end{array}$ & TransportCost & $\begin{array}{c}\text { Estimated } \\
\text { Distance of the } \\
\text { Producer from } \\
\text { the Market }\end{array}$ & $\begin{array}{c}\text { Quantity of } \\
\text { Product Ensuring } \\
\text { Profitability of } \\
\text { Deliveries }\end{array}$ & $\begin{array}{c}\text { Number of } \\
\text { Consumers } \\
\text { Served }\end{array}$ \\
\hline from 3 to $5 \mathrm{~kg}$ & PLN 5 & PLN 2/km & $70 \mathrm{~km}$ & $56 \mathrm{~kg}$ & od 11 do 19 \\
\hline
\end{tabular}

Source: authors' compilation based on the survey questionnaire.

As the presented data shows, selling carp directly to consumers is possible in the case of delivery to a group ranging from 11 to 19 consumers. 


\subsection{Assessment of the Impact of Qualitative Factors}

It is generally believed that consumers are willing to pay more for a product that meets their individual preferences. As part of this survey, respondents were asked to identify the qualitative factors of particular importance to them while making the decision to purchase carp. They were listed earlier in the article.

First, we analyzed whether the consumers making their choice based on the product price were willing to pay other amounts for fish than those for whom this factor does not matter. The application of both the Kolmogorov-Smirnov test ( $p$-value $>0.1$ ) (resistant to possible dispersion differences) and the Mann-Whitney $\mathrm{U}$ test $(p$-value $=0.32)$ show that the price factor does not affect the willingness to pay for fish. As Levene's test with $p$-value $=0.15$ shows, the dispersion in both groups of consumers is the same; therefore, one can assume that the price factor does not entirely affect the decision on how much the consumer actually wants to pay. Respondents were prepared to pay PLN 15 for fish directly from the seller and PLN 20 for fish with home delivery. Similar conclusions can be drawn in the case of price with delivery. Moreover, in the latter case, no clear differences regarding price preferences in both subgroups of consumers were observed.

The research findings allow us to conclude that consumers accept a priori the price of carp they approve of. It could even be stated that it is a kind of "fixed price". Hence, the price reduction will not result in a significant increase in the demand for carp (the demand will persist inflexible). In the event of a price increase, a dual market reaction can be expected. Firstly, if the price increase does not exceed the price approved by the consumers (PLN 15/kg if purchased from the producer and PLN 20/kg with home delivery) the demand will not decrease significantly (inflexible demand). If, however, the price exceeds the accepted value, consumers will give up purchasing carp. It can, therefore, be argued that using the price mechanism will not obtain equilibrium on the carp market.

The analysis was repeated for the qualitative factors. Only in the case of the qualitative factor "if the fish is filleted", the heterogeneity of variance is true for both variables. Despite this reservation, the application of the Kolmogorov-Smirnov test shows that respondents do not differentiate the declared prices depending on qualitative factors. Using this procedure for the other qualitative factors, a general conclusion can be formulated: regardless of the quality, origin, or individual preference for serving or culinary traditions, the declared typical price per $\mathrm{kg}$ of carp meat purchased from a producer is about PLN 15 and, when purchased with home delivery, PLN 20. Thus, Hypothesis 2 was refuted. None of the qualitative factors affected the product price.

\subsection{Assessment of the Consumption Period Impact on the Preferred Carp Purchase Price}

The final stage of the presented analysis consisted of verifying the third research hypothesis regarding the influence of the Christmas season in Poland on the willingness to pay a higher price for carp. Moreover, in this case, the abovementioned test procedure was used. For variable price at the producer and price with home delivery, in both consumer groups (Christmas buyers and buyers on other occasions), the variances are the same at the p-value level ( 0.48 and 0.36 , respectively). The Kolmogorov-Smirnov test and the Mann-Whitney $U$ test also show statistically significant differences between the declared prices. Based on the estimation of positional statistics, the price of carp can be determined in two groups of consumers: occasional and more regular consumers, as shown in Table 2:

Table 2. The analysis of carp prices among consumers in PLN.

\begin{tabular}{ccccc}
\hline & \multicolumn{2}{c}{ Consuming at Christmas Time } & \multicolumn{2}{c}{ Consuming on Other Occasions } \\
\cline { 2 - 5 } & Average & Median & Average & Median \\
\hline Price at the producer & 16 & 15 & 14 & 12 \\
\hline Price with home delivery & 21 & 20 & 19 & 18 \\
\hline
\end{tabular}


Therefore, we can ultimately assume that research hypothesis number three is true, i.e., the preferred price for carp meat depends on the regularity of consumption. If it is occasional, only at Christmas time, then it is higher than when consumers regularly buy carp.

The presented considerations conclude that consumers are prepared to pay about PLN 5 more for goods delivered to their homes. The preferred price for goods purchased from a producer is PLN 15. The price with home delivery is PLN 20.

The research also shows that none of the analyzed qualitative factors have an impact on consumers' willingness to pay a higher price for goods. People for whom price remains an essential factor in making purchasing decisions are willing to spend the same amount of money as those who do not pay much attention to this factor. It should also be noted that price was influenced by the purchase frequency. Consumers who bought carp only during Christmas were willing to pay more than those who regularly bought carp.

\section{Discussion}

Our research confirmed the specificity of the carp market. On its basis, it can be concluded that, in the case of carp, the prevailing arguments regarding the significance of price and the correlation between price and qualitative factors have not been confirmed.

It is worth emphasizing, however, that previous publications did not highlight the absence of correlation between the price and qualitative factors. As a rule, the research focused on identifying factors that influenced the functioning of the fish market, including carp. Alternatively, the analyses covered the impact of individual factors on the market [12].

As a result, the previous studies carried out in Poland show that the consumers, when purchasing fish, pay attention to qualitative factors such as freshness, smell, and meat color [34]. However, these studies did not attempt to analyze correlations between the qualitative factors and price. Therefore, we do not know whether consumers would be willing to differentiate price depending on product quality.

In general, no research attempt to correlate quality and price has been conducted on Poland's carp market. It has been a priori adopted that such a correlations occur. However, the obtained research results are contrary to this assumption. Consumers, despite their declarations, are actually not willing to differentiate price depending on product quality. They adopt an acceptable price level and are not willing to pay more, even for a higher quality product. This puts into question the possibility for producers to seek competitive advantages in organic production.

Due to the absence of comprehensive research results, until now it has been believed that the problem of fish market prices (including carp) has been approached from only a single perspective. Our research focused on answering whether price is a determining factor for purchasing fish. The problem, formulated in this way, translated into survey questions and resulted in predictable outcomes. Consumers pointed to price as the factor that influenced their purchase; the only difference in the conducted analyses consisted in determining the "power" of this factor differently. According to some authors [35], price was an important factor that determined fish purchases $(67.4 \%$ of the respondents expressed this opinion). According to others [34], the price remained a secondary factor.

The relevant literature also presented studies that highlighted how price is a barrier to developing the Polish fish market [36]. However, these studies covered the entire fish market, including marine fish. The aforementioned research showed that Poles most often chose fish such as pollock, cod, carp, trout, pangasius, and salmon. It is surprising for carp to rank high on the above list, especially in the context of our research. It is possible that consumers in our survey indicated the fish they knew (and consumed around Christmas), which does not mean that they actually regularly bought it. Nevertheless, price can be a barrier when frequently purchasing fish. Currently, such a situation did not apply to the carp market.

According to Lasner et al. [24], changing consumer preferences, price competition, imbalances at the value chain, low levels of innovation, lack of farm successors, high fish losses to predation, 
diseases, shortage of water, rural de-population, and strong seasonality of demand (peaking around Christmas) are forcing carp farmers to seek new business strategies by developing hatcheries, nurseries, storage and processing facilities, farm shops, and fish restaurants. This type of diversification can significantly increase the price of carp.

The relevant literature also presents opinions about how the fish market is sensitive to price changes, especially against the meat market [37]. However, this hypothesis was not confirmed in our research carried out on the market of carp from the Barycz Valley. It is possible that the above situation is influenced by the specificity of carp consumption and the observed increase in consumer wealth.

A similar situation is true for the carp market in Germany, which is also characterized by certain seasonality. Some research [24] has shown that in the region of Aischgrund, in 2015-2017, the wholesale price of certified carp remained at the stable level of $€ 3.00 / \mathrm{kg}$ for carp farmers. Thus, it can be concluded that there is constant demand for certified local carp in Germany. According to Lasner et al., there is an urgent need for a significant increase in the price of carp. However, as Zander et al. [38] emphasized, German consumers are more reluctant about eating carp than Polish consumers because of the lack of familiarity with and knowledge about carp.

The general trend of increasing demand for carp products in the Christmas period can also be observed in Hungary. In addition to the supply and demand relation, consumption is mostly triggered by consumer prices in which a periodical difference can be observed, since production is season-dependent and there is more fish in the winter than in the summer, while the storage of fish is expensive and even risky [39]. However, in Hungary, the demand is bigger than supply, resulting in the constant increase in carp imports from the Czech Republic [40].

In the case of other types of fish and seafood sold seasonally, an increase in prices resulting from seasonality can be observed. For example, Samy-Kamal [41] found that, in Egypt, fish and seafood prices are stable throughout the year except in April, August, October, and November; they reach their maximum level in December. In the author's opinion, the fluctuation in availability (e.g., supply) of some wild fish species (especially small pelagic species, e.g., sardines), due to their seasonality, affects their prices. Moreover, it was shown that the demand resulting from cultural aspects (traditions) strongly determines prices. The peak in April is attributed to the increase of demand coinciding with Easter in which most Copts do not eat meat or poultry, and seafood is their main protein alternative. By chance, during some years of the study, April also coincided with the month of Ramadan in which prices of all food normally increase due to higher demand. Similarly for December and August in which higher demand for seafood occurs because of Christmas, the New Year, and summer holiday.

Comparable studies were carried out in the Mediterranean region, highlighting a strong correlation between price and seasonality of red shrimp during summer holiday, Christmas, and the New Year [42]. During the year, red shrimp prices varied up to $40 \%$ between months.

The important seasonality in red shrimp prices (where from June to December prices are more than 15\% higher than April prices) is because demand, and consequently prices, increase for the Christmas and New Year's period (December registers a $40 \%$ price increase).

The limited sensitivity of consumers to changes in the price of carp should provide important information for producers. According to the research carried out in 2018, 79.4\% of the total carp available on the market was sold [43]. It is worth emphasizing that a lower sale was accompanied by a price reduction. This fact leads to the conclusion that, in the current study's situation, it is not possible to stimulate demand and increase sales by reducing the price.

Price reductions in the carp market can be placed in the broader context of analyses covering the production and sale of seasonal food products. The respective example is the production and sale of turkey meat in the U.S., which is largely consumed during the Thanksgiving holiday period [44]. In the U.S. turkey market, the difference in price between frozen and fresh meat is noticeable. In 2020, a pound of frozen meat costs an average of 84 cents, while a pound of fresh meat costs USD \$1.45. This is due to the fact that the demand for fresh meat is inelastic and thus customers are less price sensitive. Consumers traditionally prefer to buy fresh turkey, which is the main dish during a family 
gathering (similarly to carp in Poland). It is also worth emphasizing that a significant reduction in the price of turkey meat occurs in December. In the case of frozen meat, the price drop may even be sixfold. It results from the declining demand for turkey meat, which is less popular than beef and pork.

These data confirm the previous considerations regarding the carp market and prove that, in the case of products characterized by high seasonal sales fluctuations, and the consumption of which is additionally related to tradition, the price does not remain the crucial factor IN determining the purchase/sale of the product.

However, other food products consumed around the world with high seasonal demand, correlated with a national or religious holiday, can be considered as being consumed all year round, but to a lesser extent. The uniqueness of Poland's carp market results from the absence of such correlations due to the fact that, unlike other seasonal products, carp is not a permanent element of nutrition.

\section{Conclusions}

The present study's results concluded that the regulating function of price on the carp market was not working. Therefore, it could not be used as an actual impact factor. Price reduction did not result in higher demand for carp and, rather, there seemed to be a price gap, i.e., consumers were willing to pay more per $1 \mathrm{~kg}$ of carp than the current prices. Therefore, it should be assumed that a possible increase in price will not result in lower demand.

This is due to the fact that transactions between consumers and carp producers are incidental. They come down to a one-time sale and purchase transaction during the Christmas season. At the same time, for the consumer, the costs associated with purchasing carp (calculated as the quotient of price and quantity) amount to PLN 63 per year, assuming that the price is PLN 15 and the consumer buys $4.2 \mathrm{~kg}$. Therefore, it can be assumed that, from the consumer's perspective, it is not a significant expense and, thus, remains insensitive to price fluctuations.

Carp price was not influenced by qualitative factors. Although consumers declared taking quality factors into account while making purchases, our findings did not show that they actually connected quality and price.

As a result, the situation on the carp market is not determined by the price level, but rather by the non-price factors related to consumer tastes or, more broadly, sociological and psychological factors (seasonality of demand). Therefore, restoring balance to the carp market requires marketing activities that affect trends and preferences followed by $=$ consumers. The information oriented actions are also required to highlight the health benefits of carp meat consumption.

However, by confronting the collected research findings with the results of studies by other authors it may be observed that, along with the increase in carp consumption, the role of price will grow. Regular consumption of carp would result in a higher share of spending on the purchase of carp in consumers' budgets, enhancing greater price elasticity and demand. As a result, the price would regain its regulatory function.

Author Contributions: Conceptualization, M.R., M.K.-M., and M.S.; methodology, M.R., M.K.-M., and M.S., and M.N., investigation, M.R., M.K.-M., and M.S.; resources, M.R., M.K.-M., and M.S.; writing-original draft preparation, M.R., M.K.-M., and M.S., and M.N.; writing-review and editing, M.R., M.K.-M., and M.S., and M.N., visualization, M.R.; project administration, M.R.; funding acquisition, M.R., M.K.-M., and M.S., and M.N. All authors have read and agreed to the published version of the manuscript.

Funding: This research received no external funding.

Acknowledgments: This research was co-financed under the Leading Research Groups support project from the subsidy increased for the period 2020-2025 in the amount of $2 \%$ of the subsidy referred to Art. 387 (3) of the Law of 20 July 2018 on Higher Education and Science, obtained in 2019.

Conflicts of Interest: The authors declare no conflict of interest. 


\section{Appendix A Questionnaire}

1. Place of residence

2. Net income per family member

3. Do you think fish consumption is important to your health?

4. How often do you eat fish?

5. What kind of fish did you eat most often (last year)?

6. Do you eat carp?

7. Do you know the brand of carp from the Barycz Valley?

8. Would you be able to buy carp yourself directly from producers?

9. How many $\mathrm{km}$ are you able to travel to buy carp from the producer?

10. How often do you eat carp?

11. Where do you buy carp?

12. Do you pay attention to where the carp comes from?

13. In what form do you buy carp?

14. In what form would you like to buy carp?

15. How many kilograms of carp do you buy per year?

16. Assuming you have no budgetary limitations, how many kilograms of carp would you like to purchase per year?

17. Assuming you have no budgetary limitations, how often would you like to eat carp?

18. What price for live carp are you willing to accept (per $\mathrm{kg}$ )?

at the producer

with home delivery

19. What price for a carp dish can you accept in a restaurant?

20. What are your main considerations when making the decision to purchase carp?

21. What are the most important factors limiting carp consumption?

22. Do you think that you should eat fish?

23. Would you be interested to participate in the carp purchasing group (regular deliveries, prepayments)?

24. Would you like to visit a fish farm and learn about the farming process?

\section{References}

1. Marshall, A. Principles of Economics; MacMillan \& Co.: London, UK; New York, NY, USA, 1890.

2. Schindler, R.M. Pricing Strategies: A Marketing Approach; SAGE Publications, Inc.: London, UK, 2011.

3. Kotler, P.H.; Keller, K. Marketing Management, 15th ed.; Pearson: London, UK, 2014.

4. Kowalska, A.; Olszańska, A.; Urban, S. Marketing Produktów Spożywczych I Gastronomii [Marketing of Food Products and Gastronomy]; Wydawnictwo Uniwersytetu Ekonomicznego We Wrocławiu: Wrocław, Poland, 2016; p. 115.

5. Lombart, C.; Labbé-Pinlon, B.; Filser, M.; Antéblian, B.; Louis, D. Regional product assortment and merchandising in grocery stores: Strategies and target customer segments. J. Retail. Consum. Serv. 2018, 42, 117-132. [CrossRef]

6. Simonetti, L. The ideology of Slow Food. J. Eur. Stud. 2012, 42, 168-189. [CrossRef]

7. Focker, M.; van der Fels-Klerx, H.J. Economics applied to Food Safety. Curr. Opin. Food Sci. 2020. [CrossRef]

8. Aprile, M.C.; Caputo, V.; Nayga, R.M., Jr. Consumers' Preferences and Attitudes Toward Local Food Products. J. Food Prod. Mark. 2016, 22, 19-42. [CrossRef]

9. Hełdak, M.; Kurt Konakoğlu, S.S.; Kurtyka-Marcak, I.; Raszka, B.; Kurdoğlu, B.Ç. Visitors' Perceptions towards Traditional and Regional Products in Trabzon (Turkey) and Podhale (Poland). Sustainability 2020, 12, 2362. [CrossRef] 
10. Jad'ud'ová, J.; Marková, I.; Hroncová, E.; Vicianová, J.H. An Assessment of Regional Sustainability through Quality Labels for Small Farmers' Products: A Slovak Case Study. Sustainability 2018, 10, 1273. [CrossRef]

11. Bryła, P. Regional Ethnocentrism on the Food Market as a Pattern of Sustainable Consumption. Sustainability 2019, 11, 6408. [CrossRef]

12. Raftowicz, M.; Le Gallic, B. Inland aquaculture of carps in Poland: Between tradition and innovation. Aquaculture 2020, 518, 734665. [CrossRef]

13. Kieljan, K.O. Systemach Jakości Żywności, Vademecum Funkcjonowania Produktów Regionalnych I Tradycyjnych [About Food Quality Systems, Vademecum of Functioning of Regional and Traditional Products]; CDR: Kraków, Poland, 2011; p. 7.

14. Scharber, H.; Dancs, A. Do locavores have a dilemma? Economic discourse and the local food critique. Agric. Hum. Values 2016, 33, 121-133. [CrossRef]

15. Raftowicz, M.; Kalisiak-Mędelska, M.; Struś, M. Redefining the Supply Chain Model on the Milicz Carp Market. Sustainability 2020, 12, 2934. [CrossRef]

16. Roman, S.; Sánchez-Siles, L.M.; Siegrist, M. The importance of food naturalness for consumers: Results of a systematic review. Trends Food Sci. Technol. 2017, 67, 44-57. [CrossRef]

17. Raftowicz, M.; Kalisiak-Mędelska, M.; Kurtyka-Marcak, I.; Struś, M. Krótkie Łańcuchy Dostaw Na Przykładzie Karpia Milickiego [Short Supply Chains on the Example of the Milicz Carp]; CeDeWu: Warszawa, Poland, 2019.

18. Hryszko, K.; Lirski, A.; Myszkowski, L.; Wolnicki, J. Niezależne Sprawozdanie Z Obrotu Ryb I Skorupiaków Krajowej Akwakultury-Ocean Dobrych, Zrównoważonych Perspektyw Rynkowych [Independent National Aquaculture Fish. and Shellfish Marketing Report-The Ocean of Good, Sustainable Market Prospects]; Instytut Rybactwa Śródlądowego w Olsztynie [The Stanisław Sakowicz Inland Fisheries Institute in Olsztyn]: Olsztyn, Poland, 2018; p. 12.

19. Kupren, K.; Turkowski, K.; Hakuć-Błażowska, A.; Czarkowski, T.K. Rybactwo śródlądowe jako narzędzie ochrony ekosystemów wodnych oraz przykład zrównoważonej gospodarki żywymi zasobami wód [Inland fisheries as a tool for the protection of aquatic ecosystems and an example of sustainable management of living water resources]. In Ekologiczne Problemy Zrównoważonego Rozwoju [Ecological Problems of Sustainable Development]; Kiełczewski, D., Dobrzańska, B., Eds.; Wydawnictwo Wyższej Szkoły Ekonomicznej w Białymstoku: Białystok, Poland, 2009; pp. 247-257.

20. Tymińska, I.; Bujalska, A.; Dohojda, A.; Siwińska, J.; Sikorski, J.; Sulik, E.; Tylman, J. Ryby Hodowane W Polsce [Fish. Farmed in Poland]. Available online: https://www.otwarteklatki.pl/publikacje/ryby (accessed on 17 October 2020).

21. Raftowicz, M.; Struś, M.; Wodnicka, M. The need to rebuild the food supply chain. In Knowledge on Economics and Management: Profit or Purpose, Proceedings of the KNOWCON Conference, Olomouc, Czech Republic, 5-6 September 2019; Talášek, T., Stoklasa, J., Slavícková, P., Eds.; Palacký University: Olomouc, Czech Republic, 2019.

22. COM. 229 Final Communication from the Commission to the European Parliament, the Council, the European Economic and Social Committee and the Committee of The Regions Strategic Guidelines for the Sustainable Development of EU Aquaculture; COM: Brussels, Belgium, 2013; Available online: https://eur-lex.europa.eu/legal-content/ EN/TXT/PDF/?uri=CELEX:52013DC0229\&from=EN (accessed on 11 December 2020).

23. Kwasek, M. Typologia Krajów Unii Europejskiej Według Wzorców Konsumpcji Żywności, Studia I Monografie [The Typology of the European Union Countries in Accordance with Food Consumption Patterns, Studies and Monographs] No. 144; Institute of Agricultural and Food Economics: Warsaw, Poland, 2008.

24. Lasner, T.; Mytlewski, A.; Nourry, M.; Rakowski, M.; Oberled, M. Carp land: Economics of fish farms and the impact of region-marketing in the Aischgrund (DEU) and Barycz Valley (POL). Aquaculture 2020, 519, 734731. [CrossRef]

25. Report: Kompleksowy System Przetwarzania Karpi Na Nowoczesne Produkty Spożywcze I Paszowe [A Comprehensive Carp Processing System for Modern Food and Feed Products], Koszalin 2014. Available online: Karp.wm.tu.koszalin.pl/dane/raport_techniczny1.pdf (accessed on 11 December 2020).

26. Brinson, A.; Min-Yang, L.; Rountree, B. Direct marketing strategies: The rise of community supported fishery programs. Mar. Policy 2011, 35, 542-548. [CrossRef]

27. Gallegati, M.; Giulioni, G.; Kirman, A.; Palestrini, A. What's that got to do with the price of fish? Buyers behaviour on the Ancona fish market. J. Econ. Behav. Organ. 2011, 80, 20-33. [CrossRef] 
28. Hermansen, $\varnothing$.; Dreyer, B. Challenging spatial and seasonal distribution of fish landings-The experiences from rural community quotas in Norway. Mar. Policy 2010, 34, 567-574. [CrossRef]

29. Raftowicz-Filipkiewicz, M.; Le Gallic, B.; Nourry, M.; Pirrone, C. Perception des Produits de la Pêche et de L'aquaculture en Pologne: Approche Exploratoire à Travers le Visionnage des Programmes Culinaires Télévisuels. In les Enjeux du Développment Économique, Financier et Écologique Dans Une Mondialisation Risquée, $60^{e}$ Congrès de L'association Internationale des Économistes de la Langue Française; Malaga, K., Redslob, A., Eds.; Université des Sciences Économiques et de Gestion de Poznań: Poznań, Poland, 2018.

30. Levene, H. Robust Tests for Equality of Variances. In Contributions to Probability and Statistics: Essays in Honour of Harold Hotelling; Olkin, I., Ed.; Stanford University Press: Redwood, CA, USA, 1960; pp. 278-292.

31. Blair, R.C.; Higgins, J.J. A Comparison of the Power of Wilcoxon's Rank-Sum Statistic to That of Student's t Statistic Under Various Nonnormal Distributions. J. Educ. Stat. 1980, 5, 309-335. [CrossRef]

32. Mann, H.B.; Whitney, D.R. On a test of whether one of two random variables is stochastically larger than the other. Ann. Math. Stat. 1947, 18, 50-60. [CrossRef]

33. Raftowicz-Filipkiewicz, M. Research Report on the Economic and Organizational Conditions and the Supply Chain of Carps in the Lower Silesia Province, Poland, 2016. Available online: http://www.success-h2020.eu (accessed on 17 October 2020).

34. Kreft, A.; Zabrocki, R. Postawy i zachowania konsumentów Trójmiasta na rynku karpia, [Attitudes and behaviours of Tri-City consumers on the carp market]. Res. J. Gdyn. Marit. Univ. 2010, 65, 51-60.

35. Tkaczewska, J.; Migdał, W.; Kulawik, P. Preferencje konsumentów w zakresie spożycia ryb [Consumers' preferences regarding the consumption of fish]. Komun. Ryb. Fish. News 2014, 1, 10-14.

36. Rejman, K.; Kowrygo, B.; Janowska, M. Wybory konsumentów na rynku ryb, owoców morza i ich przetworów wobec sytuacji w branży rybnej [Consumers' choices on the market of fish, seafood and their preserves in relation to the situation in the fish industry]. Handel Wewnętrzny Intern. Trade 2015, 3, 216-226.

37. Hryszko, K.; Kuzebski, E.; Lirski, A. Sytuacja na światowym rynku ryb i jej wpływ na rozwój sektora rybnego w Polsce [The situation on the world fish market and its impact on the fish sector development in Poland]. Inst. Agric. Food Econ. Natl. Res. Inst. 2014, 106, 103.

38. Zander, K.; Feucht, Y. How to increase demand for carp? Consumer attitudes and preferences in Germany and Poland. Br. Food J. 2020, 122, 3267-3282. [CrossRef]

39. Karnai, L.; Szúcs, I. Outlooks and perspectives of the common carp production. Ann. Pol. Assoc. Agric. Agribus. Econ. 2018, XX, 64-71. [CrossRef]

40. European Market Observatory for Fisheries and Aquaculture Products (EUMOFA). Price Structure in the Supply Chain for Fresh Carp in Central Europe; European Commission, Maritime Affairs and Fisheries: Brussels, Belgium, 2016; p. 15.

41. Samy-Kamal, M. Prices in the Egyptian seafood market: Insights for fisheries management and food security. Fish. Res. 2021, 233, 105764. [CrossRef]

42. Guillen, J.; Maynou, F. Importance of temporal and spatial factors in the ex-vessel price formation for red shrimp and management implications. Mar. Policy 2014, 47, 66-70. [CrossRef]

43. Lirski, A. Czy grozi nam regres w sprzedaży karpia w Polsce? [Are we at risk of regression in the sale of carp in Poland?]. Komun. Ryb. Fish. News 2019, 4, 17.

44. USDA National Retail. Report: Turkey Advertised Prices for Turkey to Consumers at Major Retail. Supermarket Outlets during the Period of 11/20 Thru 11/26. Available online: https://www.ams.usda.gov/ mnreports/pywretailturkey.pdf (accessed on 22 November 2020).

Publisher's Note: MDPI stays neutral with regard to jurisdictional claims in published maps and institutional affiliations.

(C) 2020 by the authors. Licensee MDPI, Basel, Switzerland. This article is an open access article distributed under the terms and conditions of the Creative Commons Attribution (CC BY) license (http://creativecommons.org/licenses/by/4.0/). 